\title{
CAUSES AND REMEDIES OF STUDENTS' LEARNING DIFFICULTIES IN MATHEMATICS AT SENIOR SECONDARY SCHOOLS IN KANO STATE
}

\author{
Sufiyanu Haliru Jega ${ }^{1}$, Karima Bashir (Mrs.) ${ }^{2}$ and Shehu Haruna Muza ${ }^{3}$ \\ ${ }^{1}$ Department of Science Education, Faculty of Education, Kebbi State University of Science \\ and Technology, Aliero, Kebbi State, Nigeria. \\ Phone: +2347030604890, E-mail: abuhaliru@ gmail.com \\ ${ }^{2,3}$ Department of Education, Faculty of Education, Kebbi State University of Science and \\ Technology, Aliero, Kebbi State, Nigeria.
}

\begin{abstract}
This study was carried out to find out the causes of students' learning difficulties in mathematics in senior secondary schools of Kano metropolis. For the purpose of this study, data were collected from one hundred and twenty (120) SS II and III students, fourteen (14) mathematics teachers in three (3) selected secondary school in Ungoggo, Gwale and Dala Local Government Areas of Kano State. Teachers and Students selected in the sampled schools were administered, an investigator - constructed questionnaire. The result of the study indicated that the major causes of students' learning difficulties in mathematics are: Unqualified teachers, classroom overcrowded, poor study habit of the students, lack of instructional materials for teaching mathematics, etc. Based on the findings of this study, the researchers provided the recommendations for improvement, such as government should recruit qualified teachers to teach mathematics in secondary schools, teachers should encourage their students to learn the subject through employing effective teaching methods, students should concentrate in their studies, there is need for parents, NGOs and Government to provide instructional materials for teaching mathematics in secondary schools, more especially computers.
\end{abstract}

Keywords: Cause, students, learning, difficulties, mathematics, secondary school. 


\section{Introduction}

Mathematics could be said to be the study of patterns and relationships, which can be expressed in symbols. It embraces many ideas about numbers and space, which involves problem solving activities and a very powerful way of communication (Palin and Fox, 1972).

Performances of students in mathematics tasks have generally been unimpressive and worrisome. The society's perception of mathematics as "very difficult" does not help matters as student imbibes the notion that mathematics is meant for special people not including everybody. Mathematics is a universal language that must be understood by all. A society's scientific and technological breakthrough is contingent on her citizen's performances in mathematical sciences (Dele, 2002).

Mathematics is a human invention, borne out of human inquisitive spirit and desire to solve human problems. Though mathematics was found to be a major factor in the development of man and his environment, at the same time men have also greatly influenced the development of the discipline. It can be regarded as mathematics explored outside the classroom situation to solve with precision personal and societal problems (Kolawole and Oluwatayo, 2006).

According to Obodo (2001), the way many Nigerians feel, think and act towards mathematics blindfolds them from realizing the benefits accruable from the knowledge and application of the subject. The author also pointed out that many Nigerians still regard mathematics as a difficult subject to learn and consequently do not want anything associated with it. Some people even believed that mathematics has no practical application outside the classroom settings and so they abhor, hate and dislike the subject. This is very unfortunate because probably no other subject has greater application to the society than mathematics. Mathematics is a prime instrument for understanding and exploring scientific, economic and social world.

In addition to this usefulness, mathematics serve as a tool for creating new knowledge in all fields for solving problems, stating theories and predicting outcomes.

The world today is witnessing a rapid growth in the development of science and technology with the advent of computer and other information and communication technology. It is believed that hardly can a country survive the pressure of the recent information and communication technology popularly known as I.T without mathematics (Azuka, 2000).

Ironmatu (2005) reported that Nigeria is about 50 years behind the United States of America in all ramifications. This is an indirect way of saying that Nigeria has progressed slowly scientifically, industrially, politically, socially and others since her political independence from Great Britain in the year 1960. It is obvious therefore that for Nigeria to catch up with America, Nigerians must be exposed to relevant learning experiences such as obtainable in mathematics and information technology (IT) so that it can enjoy development in all ramifications.

Therefore, looking at the explanations above, one can see that the importance of mathematics to humanity cannot be overemphasized, and effort have to be made to eradicate or wipe the 
learning difficulties that students face in learning mathematics at senior secondary school in Nigeria. By doing so, the problem of mass failure in WAEC and NECO examinations in mathematics our students are currently facing will be minimized, if not solved at all.

\section{Statement of the problem}

It has been observed that mathematics is indispensable to our life, this means we cannot live without it. Despite this usefulness, students are continued to face difficulties in learning the subject at secondary school level (Akintoya, 2001).

Mathematics is a subject that forms the major skeleton of all technological developments and play no less a role in all other subjects discipline. It develops rapidly as the technology itself advances. The teaching and learning of the subject have been hindered by some problems which include:

1. The students' inability to cope with the contents of the course unit (curriculum).

2. Students' wrong notion towards the subject matter.

3. Lack of adequate textbooks and other instructional materials.

4. Shortages of mathematics teachers.

5. Teachers' qualifications and educational background.

6. The knowledge, beliefs, understanding and practices of teachers.

7. Government negligence.

8. Societal perceptibility on the subject.

9. Lack of students/ teachers motivation.

Therefore, the study aimed at investigating the causes of students learning difficulties in mathematics. That is to say, the researchers intended to find out the causes of the students learning difficulties in mathematics at secondary schools in Kano metropolis.

\section{Objectives of the study}

The aims and objectives of this study are as follows:

1. To investigate the causes of the learning difficulties in mathematics among secondary school students.

2. To check whether the students' learning difficulties in mathematics have negative effect on the students' performance in mathematics at SSCE examinations.

3. To find out the ways of improving the teaching and learning of mathematics at secondary schools in Kano metropolis.

4. To provide solution on how to wipe or eradicate students learning difficulties in mathematics at senior secondary school.

\section{Research Questions}

1. What are the causes of students' learning difficulties in mathematics at secondary school? 
2. Do the students' learning difficulties in mathematics have effect on students' performance in SSCE examination?

3. How can the students' learning difficulties in mathematics be identified?

4. What are the possible remedies to these students' learning difficulties in mathematics?

\section{Significance of the Study}

This research work is aimed at investigating the causes of students' learning difficulties in mathematics at senior secondary schools in Kano metropolis. The study hopes to find a concrete and everlasting solution to the causes of students' learning difficulties in mathematics at senior secondary schools in Kano metropolis.

This study also intended to provide the policymakers with relevant information for the improvement of teaching and learning mathematics at secondary schools in Kano metropolis.

This study would be of immense importance to the mathematics educators, teachers as well as learners of mathematics either for employment or specialization.

The research study would also form part of the existing literatures which would be useful for future researchers on the similar topic.

It can also help the parents to know whether their children are affected by learning difficulties in mathematics, so that they can help their children to overcome these problems.

\section{Scope of the study}

This study intended to investigate the causes of students' learning difficulties in mathematics and limited to some selected secondary schools in Kano metropolis. Therefore, the research is to focus on three (3) secondary schools in Kano metropolis. The schools are Government Secondary School (GSS) Warure, Government Secondary School (GSS) R/Zaki and Government Girls College Dala (GGC Dala). These schools are situated in Ungogo, Gwale and Dala local government areas respectively.

\section{Literature Review}

\section{The Concept of Secondary School}

Secondary school is the school children attain after primary school and before tertiary stage (NPE, 2004). With the introduction of 6-3-3-4 system of education in Nigeria, the child will spend 6 years in primary school, 3 years in junior secondary school, and 3 years also in senior secondary school and 4 years in tertiary institutions of learning. Like other countries in Africa, primary school children age in Nigeria range between $6-12$ years, junior secondary range between $12-15$ years and senior secondary range between $15-18$ years.

According to NBS (National Bureau of Statistic, 2016) the enrolment in Junior/senior secondary schools in Nigeria are 7,625,943 with total schools of 19,238. The level of enrolment in junior/senior secondary in Nigeria is very low, considering the population of 180 millions. 


\section{The objectives of secondary school}

The broad goals of secondary school shall be to prepare the individual for useful living within the society and higher education. Other objectives of secondary school include:

a) Provide all primary school leavers with the opportunity for education of a higher level, irrespective of sex, social status, religious or ethnic background.

b) Offer diversified curriculum to cater for the difference in talents, opportunities and future roles.

c) Provide trained manpower in the applied science, technology and commerce at sub professional grades.

d) Develop and promote Nigerian languages, art and culture in the context of world's cultural heritage.

e) Inspire students with a desire for self improvement and achievement of excellence.

f) Foster national unity with an emphasis on the common ties that unite us in our diversity.

g) Raise a generation of people who can think for themselves, respect the views of others, respect the dignity of labor, appreciate those values specified under our broad national goals and live as good citizens.

h) Provide technical knowledge, and vocational skills necessary for agricultural, industrial, commercial and economic development.

\section{The concept of mathematics}

According to advanced learner dictionary, Mathematics is the science of numbers, quantity and space. Looking at this definition, mathematics deals with scientific study of numbers, i.e how numbers behave in the natural manner. This definition also included the types of numbers which include natural numbers $(1, \ldots, 9)$, even numbers (i.e. any number that is divisible by 2 . E.g. $2,4,6, \ldots$ ), odd numbers (i.e. numbers like $1,3,5,7, \ldots$ ). It also shows how mathematics is used in determining the quantity of an object and space it occupied.

Igbokwe (1997) defined mathematics as a body of knowledge used for estimating, calculating. Mathematics therefore has implication for human measurement in his environment. Igbokwe's definition shows the importance of mathematics in his environment, through calculation, estimating, counting and measurement.

According to Obodo (2001), Mathematics is a subject that is taught in school and can be learned from all the numerous things in the environment. Obodo's definition is similar to that of Igbokwe's own, because both definitions show the significance of the subject to the environment, but in addition to Igbokwe's definition, Obodo also highlight that mathematics is one of the subjects that are taught in school (primary, secondary and even tertiary schools). Also Obodo's definition show how mathematics can be learned from all numerous things. As such, mathematics can be applied to almost every human endeavour.

\section{The objectives of teaching mathematics}

The objectives of teaching mathematics in our schools are as follows: 
i. To inculcate critical thinking ability.

ii. To teach numeracy to children.

iii. To prepare children for business and other commercial duties.

iv. To help students for studying mathematics at tertiary level.

v. To enhance the habit of trustworthiness both in taught and practice.

\section{Learning Difficulties}

Learning difficulty (also known as learning disorder, or learning disability) is a classification including several disorders in which a person has difficulty learning in a typical manner, usually caused by an unknown factor or factors (Mclonghlin, 1998).

The unknown factors are the disorders that affect the brain's ability to receive and process information. This disorder can make it problematic for a person to learn as quickly or in the same way as someone who is not affected by a learning disability or difficulty. People with learning difficulty have trouble performing specific type of skills or completing task if left to figure things out by themselves or if taught in conventional ways (Rance and Lovis, 2002).

However, some forms of learning disabilities are incurable. But with appropriate cognitive and academic interventions many can be overcome through proper teaching techniques and the use of instructional materials to children with that type of disorder. Learning disability is usually used to describe different kinds of learning problems like learning to talk, read, write or do arithmetic.

\section{Causes of Learning Difficulties}

There are two factors that influence learning difficulties viz:

1. Pre-natal influence

2. Post natal influence

1. Pre-natal influence: are those conditions that affect a pregnant woman before the birth of an abnormal or normal child.

The factors include:

a) Infection or ill health in the mother.

b) Genetic traits from either one or both of the parents.

c) Malnutrition at the mother during pregnancy.

d) Smoking by expectant mother could lead to the birth of a handicapped/ learning disability child.

e) High blood pressure in pregnant mother could affect the baby.

f) Duration of pregnancy: if a baby is born earlier (pre-maturely under 38 weeks), the baby's brain cells may be damaged during the period of incubation due to lack of or excess supply of oxygen.

g) Mother's age: when a pregnant woman is over 38 years old, the possibility of having learning disabled child is high. 
2) Post-natal influence that causes the learning disability: These are conditions which affect the child after birth and that resulted in learning disability. Such post-natal factors include:

a) Childhood diseases such as chicken pox etc.

b) Blows of the head

c) Harsh climate conditions.

d) Accidents

e) Social and environmental conditions. A child from poor home will not have access to television, book, computer, internet and enough play materials for stimulation.

f) Slaps to the eye or ear

g) Marriage between incompatible couples (e.g. carriers of sickle cell trace)

h) Self-medication

\section{Remedies of learning difficulties}

The problem of causes of learning disability can be prevented by using following:

1. Genetics counseling: Couples who are much older should be discouraged from having birth.

2. Self-medication should be discouraged

3. Improved health care: improved health care and good medical attention for pregnant mother and babies.

4. Encourage immunization of mothers and babies

5. Pregnant mothers should be encouraged to take balanced diet.

6. Children should be provided with rich and stimulating environment (Abosi, 1981).

\section{Causes of learning difficulties in mathematics}

Math learning disability/difficulty can be a debilitating problem in school and later life. In today's world, mathematical knowledge, reasoning, and skills are no less important than the ability to read. The effect of mass failure during the years of schooling, as the mass literacy in adult life, can seriously handicap both daily living and vocational prospects.

According to the statistics, approximately $6 \%$ of school age children have significant maths difficulties and among students classified as learning disabled, arithmetic difficulties are as pervasive as reading problems. This does not mean that all reading disabilities are accompanied by mathematics problems, but it does mean that math problems are widespread and in need of equivalent attention and concern as reading problems. In the journal of learning disabilities, McLeod and Crump state that one-half of students with learning disabilities require supplemental work in mathematics.

Mathematics learning difficulty or disability, also known as "dyscalculia" which came from Greek and Latin words; the prefix "Dys" came from Greek and means "badly", "calculia" come from Latin "calculare" which means "to count". If put together "Dyscalculia" means "count badly". 
Dyscalculia is a specific learning disability involving innate difficulty in understanding or learning (comprehending) simple arithmetic. It is a kind of dyslexia and includes difficulty in understanding numbers, learning how to manipulate numbers or other related symptoms. Mathematics disability can also occur as a result of some types of brain injury, in which case the proper term is calculia, to distinguish it from dyscalculia which is of innate, genetic or developmental origin. Although mathematics learning difficulties occur in children with low I.Q. Dyscalculia can be found in people with normal to superior intelligence (Emerson, 2009).

\section{Characteristics of Dyscalculia}

The characteristics of dyscalculia are as follows:

i) Frequent difficulties with arithmetic, confusing the signs,,$+- /, \mathrm{x}$.

ii) Difficulty with everyday task like checking change and reading analog clocks.

iii) Inability to comprehend financial planning or budget the cost of the items in shopping basket or balancing a check book.

iv) Difficulty with multiplication table, subtraction table, addition table and division table.

v) Difficulty with conceptualization of time, and judging the passing of time.

vi) May be exceptionally well in writing related field. Many authors and journalist have this disorder.

vii) Mistaken recollection of names.

However, all the causes of mathematics learning difficulties can be grouped into two (2) namely as:

1. Genetic and social factors

2. Scholastic factors (United State Department of Education, 2008).

\section{1) Genetic and social factors}

These genetic and social factors include the following:

i. Problems of learning disability (mentally retarded)

ii. Having problem of dyscalculia

iii. The abstractness of the subject

iv. Students negative attitude towards learning mathematics.

v. Some students dislike or hate the subject.

\section{2) Scholastic factors}

These factors include:

i. Lack of qualified mathematics teachers

ii. Shortage of mathematics teachers 


\section{iii. Teachers poor condition of service \\ iv. Lack of ideal learning environment \\ v. Lack of training and retraining of mathematics teachers.}

Several people have written on the students learning difficulties in mathematics. A small number of students were identified as having a specific mathematical learning disability (Dyscalculia) as reported by Carneclor (2004). Booker and Swan (2005) conducted a research on causes of students learning difficulties in Mathematics; they suggest that most students and educator have created their mathematical problems by themselves. There is need for teachers regardless of the reason for students mathematical deficiency factors, to teach the subject effectively.

Sherman and Richardson (2005) believe that mathematics instruction must provide opportunity for challenging questions, problem solving, reasoning and connections within the curriculum and real- world situation so that the learner will learn the subject easily. They also commented that qualified mathematics teacher is pivotal person in ensuring successful learning of the subject (mathematics).

Ramjee (2003) conducted a survey study "on the factors affecting learning disabilities in mathematics, a study of central region of Nepal", the sample for the study consisted of 104 grade - 12 students studying in 29 rural and 15 - urban schools of central region of Nepal. The finding of the study shows that the size of the family, self study habits, socioeconomic status of the parent and parental behavior are all factors that affecting learning difficulties in mathematics.

Akintayo (2001) did a survey of the learning difficulties of mathematics in the secondary school in Ekiti central local government area of Ondo State. She made use of 100 students and all mathematics teachers in six (6) secondary schools in the area. Questionnaires were distributed to them to respond. $54 \%$ of the students agreed that one of the factors affecting mathematics learning difficulties is lack of qualified teachers to teach the subject.

Machiel (2008) carried out a research on the factors responsible for students learning difficulties in mathematics in Ilorin local government of Kwara State. He divided the school into two (2), i.e those with inadequate mathematics teachers. He administered a diagnostic test to both schools. The result show that the students in school with adequate mathematics teachers performed better than those with inadequate teachers. Therefore, he concluded that inadequate and unqualified mathematics teachers are among the factors that are responsible for students learning difficulties in mathematics.

Cott (1992) hypothesized that mathematics learning difficulties can be caused by the inability of child's blood stream to synthesize a normal amount of vitamins. To test this by hypothesis, Heat (1995) performed an experiment on effect of megavitamin therapy with mathematics learning disable children. The result shows that a huge dose of vitamins does not improve the performance of mathematics learning disabled children. 
According to Maloughlin (1998), environmental factors can cause the maths learning difficulties. He identified these as poor nutrition, health, and safety, family incomes level, study habit etc. The condition mentioned above are expected to be more prevalent and affecting adversely in rural than in urban areas.

Ngozi (2003) carried out a research on "causes of learning disability in three secondary school subjects"; among the subjects, there is mathematics. The study consists of five (5) secondary schools in Enugu south local government area of Enugu state, Nigeria - two (2) private-owned and three (3) government-owned schools respectively. The two private schools considered to be standard schools with adequate instructional materials, while the three public schools are termed to be substandard schools with inadequate infrastructural facilities for teaching and learning the three subjects. The finding of the study revealed that a school with inadequate instructional materials for teaching has the problems of learning disability in all the three subjects. Therefore, she recommended the use of instructional materials for teaching mathematics and other school subjects.

Looking at the above empirical studies on the subject matter, it is seen that most of the studies that have been conducted are in southern part of this country, some were even conducted outside the country. No study done in Northwestern part of the country (Nigeria) could be identified for review. In light of the above consideration, this study was conducted to investigate the causes of learning difficulties in mathematics among secondary schools in Kano metropolis.

\section{Methodology}

\section{Research Design}

The research design adopted for this study was the descriptive survey design. According to Gay (1992), a survey research is an attempt by researcher to collect data from members of a population (i.e both teachers and students) in order to determine the current status of that population with respect to one or more variables. In other words, survey involves the collection of data from population and drawing inferences from the collected data on the population.

In this research work, the researcher used descriptive design to describe the causes of learning difficulties in mathematics among secondary schools in Kano metropolis.

\section{Population of the Study}

This research was conducted so as to investigate the causes of learning difficulties in mathematics among secondary schools in Kano metropolis. The populations of the study are all secondary schools in Kano metropolis and all mathematics teachers of the study area.

\section{Sample of the Population}

The sample of this study was drawn from three secondary schools in Kano metropolitan area. The schools were: 
i) Government secondary school (GSS) Warure

ii) Government secondary school (GSS) R/Zaki

iii) Government Girls College (GGC) Dala.

Out of the above mentioned schools, forty (40) students were randomly selected from each school making the total sample of 120 students.

\section{Sample size / Sampling Techniques}

The simple random sampling technique was used by the researchers in conducting the study; this is because the simple random sampling gives the student individual an independent chance of participating. In fact, the students were selected randomly to avoid any possibility of manipulation.

\section{Instrument}

In order to collect data, the researchers require various types of instruments. However, for the purpose of this research, the researchers used questionnaires as the potential tools for data collection.

\section{Procedure for Data Collection}

Questionnaire was used in the collection of data for this research.

Questionnaire is the list of questions to be answered by group of people in order to obtain some facts or information for a survey or research.

Questionnaires are of two types, open-ended questions and closed - ended questions.

There are two sets of questionnaires in this study, one for the teachers and the other for the students.

The questionnaire used in the cause of this study was designed to solicit information as regards to the causes of learning difficulties in mathematics among secondary schools in Kano metropolis.

\section{Method of Data Analysis}

In the analysis of the data collected, some statistical methods (techniques) involving the frequency distribution (i.e frequency table) of the responses and the percentage of the response will be employed for the purpose of calculating the percentage response.

$$
\begin{aligned}
& \text { Percentage response } \quad=\quad \sum \mathbf{x} \quad \mathrm{X} 100 \% \\
& \text { Where, } \mathrm{N}=\text { Number of respondents } \quad \text { N } \\
& \sum=\text { Summation sign indicating that } \mathbf{x} \text { in the item are added. }
\end{aligned}
$$


The interpretation will be mainly descriptive in order to facilitate simplicity and easy comprehension. Therefore, the responses with the highest percentage in each item will be accepted as the opinion of the majority of the respondents (teachers and students).

\section{Analysis}

\section{Description of teachers' responses}

Table1: Teachers' response by sex.

\begin{tabular}{|l|l|l|}
\hline SEX & FREQUENCY & PERCENTAGE \\
\hline MALE & 9 & 64.3 \\
\hline FEMALE & 5 & 35.7 \\
\hline TOTAL & $\mathbf{1 4}$ & $\mathbf{1 0 0 . 0} \%$ \\
\hline
\end{tabular}

From the above table, it shows that $9(64.3 \%)$ of the teachers that responded were male and $5(35.7 \%)$ were female.

Table 2: $\quad$ Teachers' age, qualification and teaching experience and work load and number of students in the class

\begin{tabular}{|c|c|c|c|c|c|}
\hline Items & $\begin{array}{l}\text { No of } \\
\text { respondents }\end{array}$ & $\begin{array}{l}\text { Description of } \\
\text { statement }\end{array}$ & Opinion & Frequency & Percentage \\
\hline 2 & 14 & Age & $\begin{array}{l}20-25 \\
26-30 \\
30-40 \\
40+\end{array}$ & $\begin{array}{l}1 \\
3 \\
7 \\
3\end{array}$ & $\begin{array}{l}7.1 \% \\
21.4 \% \\
50 \% \\
21.4 \%\end{array}$ \\
\hline 3 & 14 & Qualification & $\begin{array}{l}\text { Ph.D/Msc/M.Ed Maths } \\
\text { Bsc(Ed)/B.Ed Maths } \\
\text { NCE (Mathematics) } \\
\text { Bsc/B. Engr. } \\
\text { others }\end{array}$ & $\begin{array}{l}0 \\
5 \\
4 \\
1 \\
4\end{array}$ & $\begin{array}{l}0.0 \% \\
35.7 \% \\
28.6 \% \\
7.1 \% \\
28.6 \%\end{array}$ \\
\hline 4 & 14 & $\begin{array}{l}\text { Years of teaching } \\
\text { experience }\end{array}$ & $\begin{array}{l}\text { over } 10 \text { years } \\
5-9 \text { years }\end{array}$ & $\begin{array}{l}6 \\
3\end{array}$ & $\begin{array}{l}42.9 \% \\
21.4 \%\end{array}$ \\
\hline
\end{tabular}




\begin{tabular}{|c|c|c|c|c|c|}
\hline & & & $\begin{array}{l}2-4 \text { years } \\
1-2 \text { years } \\
\text { below } 1 \text { years }\end{array}$ & $\begin{array}{l}3 \\
0 \\
2\end{array}$ & $\begin{array}{l}21.4 \% \\
0.0 \% \\
14.3 \%\end{array}$ \\
\hline 5 & 14 & $\begin{array}{l}\text { Number of } \\
\text { students in the } \\
\text { class }\end{array}$ & $\begin{array}{l}\text { over } 100 \\
70-100 \\
30-69\end{array}$ & $\begin{array}{l}2 \\
2 \\
10\end{array}$ & $\begin{array}{l}14.3 \% \\
14.3 \% \\
71.4 \%\end{array}$ \\
\hline 6 & 14 & $\begin{array}{l}\text { Teachers work } \\
\text { load }\end{array}$ & $\begin{array}{l}12 \text { period/week } \\
13-19 \text { periods } \\
20-30 \text { periods }\end{array}$ & $\begin{array}{l}1 \\
2 \\
11\end{array}$ & $\begin{array}{l}7.1 \% \\
14.3 \% \\
78.3 \%\end{array}$ \\
\hline & & & above 30 & 0 & $0.0 \%$ \\
\hline
\end{tabular}

From table 2 above, it shows that item 2 which indicates the age of the teacher 1 $(7.1 \%)$ was range from $(20-25)$ years, $3(21.4 \%)$ were from $(30-40)$ years, $3(21.4 \%)$ were range from $(40+)$ years

The item 3, i.e. the qualification of teachers teaching mathematics in the selected schools, 0 Ph.D means none of the teachers have Ph.D, 5 (35.7\%) of teachers are B.sc (Ed) /B.sc/Bed mathematics holders, $4(28.6 \%)$ of teachers, 1 (7.1) of teachers are B.sc/B. engineering holders, and 4 (28.6\%) of teachers are masters/ OND/HND or B.Sc physics holders

The item 4, i.e. the years of teaching experience of mathematics teachers in the selected schools; 6 (42.9\%) have over 10 years of teaching experience, $3(21.4 \%)$ have the range of 5 - 9 years of teaching experience, $3(21.4 \%)$ have the range of $2-4$ years of teaching experience and lastly $2(14.3 \%)$ have the range of below 1 year of teaching experience.

The item 5, i.e. number of students in the class (number of students per teacher); $2(14.3 \%), 2$ $(14.3 \%)$ of teachers have the range of $70-100$ students in the class and $10(71.4 \%)$ of teachers have the range of $30-69$ students in the class.

From the table 3 above, item 7, i.e. option on adequate instructional materials for teaching mathematics in the schools selected for the study. The question required yes or no, 4 (28.6\%) of teachers respond yes while $10(71.4 \%)$ teachers respond NO. Also in item 8, i.e. question on enough mathematics teachers in the schools, 5 (35.7) of teachers respond YES while 9 $(64.3 \%)$ of teachers respond NO, in item 9, i.e. have you ever attended workshop on mathematics? $7(50 \%)$ of teachers respond NO. On the item 10, on the question about whether a teacher can improve an instructional material for teaching mathematics? 12 $(85.7 \%)$ of teachers respond YES while $2(14.3 \%)$ of teachers respond NO.

The item 11, i.e. Do you think the time allocated to mathematics lesson per period is enough? $11(78.68 \%)$ of teachers respond YES while $3(21.4 \%)$ of teachers respond NO. Item 12, i.e. 
question about, whether there are adequate mathematics textbooks, 9 (64.3\%) of teachers respond YES, while $5(35.7 \%)$ of teachers respond NO. In item 16, i.e. do you use computer in teaching mathematics, $14(100 \%)$ of the teachers responded NO. That means there is no availability of computer in the schools (G.G.C Dala, G.S.S. Warure and G.S.S. R/Zaki) selected for this study; in item 17, i.e. does it (computer) improve teaching and learning mathematics? 7 (50\%) of teachers respond YES also 7 (50\%) of teachers respond NO.

From table 4 above, item 13, i.e. question on which method teachers use in teaching their students, $8(57.1 \%)$ of teachers respond to traditional teaching method, $5(35.7 \%)$ of teachers respond to problem solving method, 1 (7.1\%) of teachers respond to lecture method.

The item 14, i.e. what are the areas (topics) of students facing difficulties in learning? 6 $(42.9 \%)$ of teachers respond to construction, $1(7.1 \%)$ of teachers respond to geometry, 5 (35.7\%) of teachers respond to word problem, and 2 (14.3\%) of teachers respond to Algebra. No responses to trigonometry and statistics/ probability.

In the item 15, i.e. what do you think are the possible causes of students' learning difficulties in mathematics? $13(92.9 \%)$ of teachers respond to poor attitude of students toward the subject (mathematics), 1 (7.1\%) of teachers respond to teaching and learning.

\section{Description of students' responses}

Percentage was used in analysis of this research and the interpretations of findings were based on the percentages. The researchers administered one hundred and twenty (120) questionnaires, in which one hundred and eighteen (118) were returned, below are the analysis and interpretation based on one hundred and eighteen (118) copies of the questionnaire obtained.

Table 5: Students responses by sex

\begin{tabular}{|l|l|l|}
\hline SEX & FREQUENCY & PERCENTAGE (\%) \\
\hline MALE & 78 & 66.1 \\
\hline FEMALE & 40 & 33.9 \\
\hline TOTAL & $\mathbf{1 1 8}$ & $\mathbf{1 0 0}$ \\
\hline
\end{tabular}

The table above shows that $78(66.1 \%)$ of the students that responded were male and 40 $(33.9 \%)$ were female. 
Table 6: Name of the students' school

\begin{tabular}{|l|l|l|}
\hline NAME & FREQUENCY & PERCENTAGE (\%) \\
\hline G. S. S. R/Zaki & 40 & 33.9 \\
\hline G. S. S. Warure & 38 & 32.2 \\
\hline G. G. C. Dala & 40 & 33.9 \\
\hline TOTAL & $\mathbf{1 1 8}$ & $\mathbf{1 0 0}$ \\
\hline
\end{tabular}

The table above shows that 40 (33.9\%) of the students that responded were from Government Secondary School, R/Zaki, 38 (32.2\%) of the student were from Government Secondary School, Warure and 40 (33.9\%) were from Government Girls College, Dala.

Table 7: Students' responses by class

\begin{tabular}{|l|l|l|}
\hline NAME & FREQUENCY & PERCENTAGE (\%) \\
\hline S. S. II & 43 & 36.4 \\
\hline S. S. III & 75 & 63.6 \\
\hline TOTAL & $\mathbf{1 1 8}$ & $\mathbf{1 0 0}$ \\
\hline
\end{tabular}

The table above shows that $43(36.4 \%)$ of students that responded were at S.S. II class, and $75(63.6 \%)$ were at S.S. III class.

Table 8 Students' responses by age

\begin{tabular}{|l|l|l|}
\hline NAME & FREQUENCY & PERCENTAGE (\%) \\
\hline $15-20$ & 113 & 95.8 \\
\hline $21+$ & 5 & 4.2 \\
\hline TOTAL & $\mathbf{1 1 8}$ & $\mathbf{1 0 0}$ \\
\hline
\end{tabular}

The table above shows the age of the students; 113 (95.8\%) were within the range of (1520) years, $5(4.2 \%)$ were within the range of $(21+)$ years. 
Table 9: Students' responses by family type

\begin{tabular}{|l|l|l|}
\hline NAME & FREQUENCY & PERCENTAGE (\%) \\
\hline Nuclear & 32 & 27.1 \\
\hline Extended & 86 & 72.9 \\
\hline TOTAL & $\mathbf{1 1 8}$ & $\mathbf{1 0 0}$ \\
\hline
\end{tabular}

The table above shows that $32(27.1 \%)$ of the students that responded were from nuclear family, and 86 (72.9) were from extended family.

Table 10: Students' responses based on alternative question (YES or NO)

\begin{tabular}{|c|c|c|c|c|c|c|}
\hline \multirow[b]{2}{*}{ ITEMS } & \multirow[b]{2}{*}{$\begin{array}{l}\text { NO. OF } \\
\text { RESPONSE }\end{array}$} & \multirow[b]{2}{*}{ DESCRIPTION OF STATEMENT } & \multicolumn{4}{|c|}{ OPTION } \\
\hline & & & YES & $\%$ & NO & $\%$ \\
\hline 6 & 118 & $\begin{array}{l}\text { Does your parent buy any instructional } \\
\text { materials e.g. maths set, calculator, textbooks } \\
\text { etc. }\end{array}$ & 42 & 35.6 & 76 & 64.4 \\
\hline 8 & 118 & $\begin{array}{l}\text { Do you think you can achieve your career } \\
\text { without mathematics }\end{array}$ & 21 & 17.8 & 97 & 82.2 \\
\hline 11 & 118 & $\begin{array}{l}\text { Does a mathematics teacher in your school } \\
\text { attend class regularly }\end{array}$ & 104 & 88.1 & 14 & 11.9 \\
\hline 13 & 118 & $\begin{array}{l}\text { Are you satisfied with the methods your } \\
\text { mathematics teachers use- in teaching you? }\end{array}$ & 83 & 70.3 & 35 & 29.7 \\
\hline 14 & 118 & $\begin{array}{l}\text { Do you use computer in learning } \\
\text { mathematics? }\end{array}$ & 35 & 29.7 & 83 & 70.3 \\
\hline 15 & 118 & $\begin{array}{l}\text { Does computer improve your learning of } \\
\text { mathematics }\end{array}$ & 25 & 21.2 & 93 & 78.8 \\
\hline
\end{tabular}

Table 10 shows that 118 were responded and thus used for the analysis. Item 6 i.e. does your parent buy any instructional materials e.g. calculator, mathematical set, textbook etc in which $42(35.6 \%)$ of the students answered YES, and $76(64.4 \%)$ answered NO. This indicated that majority of the students' parents bought instructional materials for them. 
Item 8 , i.e do you think you can achieve your career without mathematics? In which $17.8 \%$ of the students agreed, while $82.2 \%$ disagreed. This implies that it will be difficult for the students to achieve their career without mathematics.

Item 11, i.e does a mathematics teacher in your school attend class regularly? $88.1 \%$ of the students agreed, while $11.9 \%$ disagreed. This indicates that the mathematics teacher does not attend class regularly.

Item 13, i.e. are you satisfied with the methods your mathematics teacher use in teaching you? $70.3 \%$ of students agreed, while $29.7 \%$ disagreed. This shows that mathematics teachers use sufficient method of teaching mathematics.

Table 11: Students' responses based on closed ended questions.

\begin{tabular}{|c|c|c|c|c|c|}
\hline ITEMS & $\begin{array}{l}\text { NO. OF } \\
\text { RESPONSE }\end{array}$ & $\begin{array}{l}\text { DESCRIPTION OF } \\
\text { STATEMENT }\end{array}$ & OPTION & FREQUENCY & PERCENTAGE \\
\hline 7 & 118 & $\begin{array}{l}\text { What do you like to } \\
\text { study after your } \\
\text { secondary education }\end{array}$ & $\begin{array}{l}\text { Art/humanities, } \\
\text { Science, } \\
\text { Eng. technology }\end{array}$ & $\begin{array}{l}35 \\
60 \\
23\end{array}$ & $\begin{array}{l}29.7 \% \\
50.8 \% \\
19.5 \%\end{array}$ \\
\hline 9 & 118 & $\begin{array}{l}\text { What is your study } \\
\text { habit }\end{array}$ & $\begin{array}{l}\text { Reading1 hours } \\
\text { Reading2 hours } \\
\text { Reading above } 2 \\
\text { hours }\end{array}$ & $\begin{array}{l}15 \\
25 \\
78\end{array}$ & $\begin{array}{l}12.7 \% \\
21.2 \% \\
66.1 \%\end{array}$ \\
\hline 10 & 118 & $\begin{array}{l}\text { Which subject do you } \\
\text { like most }\end{array}$ & $\begin{array}{l}\text { English } \\
\text { Mathematics } \\
\text { Economics } \\
\text { Others (Specify) }\end{array}$ & $\begin{array}{l}34 \\
51 \\
18 \\
15\end{array}$ & $\begin{array}{l}28.8 \% \\
43.2 \% \\
15.3 \% \\
12.7 \%\end{array}$ \\
\hline 12 & 118 & $\begin{array}{l}\text { What is your } \\
\text { performance in } \\
\text { mathematics in the last } \\
\text { term examination? }\end{array}$ & $\begin{array}{l}70-100 \\
50-59 \\
40-49 \\
\text { below } 40\end{array}$ & $\begin{array}{l}20 \\
48 \\
35 \\
15\end{array}$ & $\begin{array}{l}16.9 \% \\
40.7 \% \\
29.7 \% \\
12.7 \%\end{array}$ \\
\hline 13 & 118 & $\begin{array}{l}\text { Which methods of } \\
\text { teaching do your }\end{array}$ & Traditional teach & 50 & $42.4 \%$ \\
\hline
\end{tabular}




\begin{tabular}{|c|c|c|c|c|c|}
\hline & & $\begin{array}{l}\text { teacher use in teaching } \\
\text { you mathematics }\end{array}$ & $\begin{array}{l}\text { Lecture method } \\
\text { Problem Solving } \\
\text { method } \\
\text { Others (specify) }\end{array}$ & $\begin{array}{l}7 \\
35 \\
\\
31\end{array}$ & $\begin{array}{l}1.69 \% \\
29.7 \% \\
26.3 \%\end{array}$ \\
\hline 14 & 118 & $\begin{array}{l}\text { What are the areas } \\
\text { (topics) in mathematics } \\
\text { do you face } \\
\text { difficulties? }\end{array}$ & $\begin{array}{l}\text { Construction } \\
\text { Geometry } \\
\text { Word Problem } \\
\text { Trigonometry } \\
\text { Algebra } \\
\text { Statistics/ } \\
\text { probability }\end{array}$ & $\begin{array}{l}40 \\
30 \\
10 \\
15 \\
8 \\
15\end{array}$ & $\begin{array}{l}33.9 \% \\
25.4 \% \\
8.47 \% \\
12.7 \% \\
6.78 \% \\
12.7 \%\end{array}$ \\
\hline 15 & 118 & $\begin{array}{l}\text { What do you think are } \\
\text { the causes of students' } \\
\text { learning difficulties in } \\
\text { mathematics }\end{array}$ & $\begin{array}{l}\text { Methodology of } \\
\text { teachers } \\
\text { Abstractness of } \\
\text { the subject } \\
\text { Poor attitude } \\
\text { towards the } \\
\text { subject }\end{array}$ & $\begin{array}{l}20 \\
20\end{array}$ & $\begin{array}{l}50.8 \% \\
16.9 \% \\
16.9 \% \\
15.3 \%\end{array}$ \\
\hline
\end{tabular}

Item 7 shows that $29.7 \%$ of the students like to study art and humanities, $50.8 \%$ like to study science and $19.5 \%$ like to study engineering technology.

Item 9, i.e. what is your study habit; $12.7 \%$ of students say they read for 1 hour, $21.2 \%$ say they read for 2 hours and $66.1 \%$ say that they read above 2 hours.

Item 10, i.e. which subject do you like most? 28.8\% responses that English is they like most, $43.2 \%$ response to mathematics, $15.3 \%$ response to economic and $12.7 \%$ response to others subject. 
Item 12, i.e. the score for mathematics in the last term examination; $16.9 \%$ of students score the range of $70-100,40.7 \%$ of students score the range of $40-49$, and 12.7 of students score below 40.

Item 13, i.e. which method of teaching does your teacher use in teaching you mathematics; 50 (42.4\% of students respond to traditional teaching method, 2 (1.69\%) respond to lecture method, 35 (29.7\%) respond to problem solving method, 31 (26.3\%) respond to other method.

Item 14, i.e. what are the areas (topics) in mathematics you (student) face difficulties? 40 (33.9) respond to construction, $30(25.4 \%)$ respond to geometry, $10(8.47 \%)$ of students respond to word problem, $15(12.7 \%)$ of students respond to trigonometry, 8 (6.7\%) respond to algebra, while $15(12.7 \%)$ of the students respond to statistics/probability.

Item 15, i.e. what do you think are the causes of students learning difficulties in mathematics? $60(50.8 \%)$ of the students respond to the methodology of the teacher, 20 (16.9\%) respond to the abstractness of the subject, 20 (16.9\%) of the students respond to poor attitude of students towards the subject, while $18(15.3 \%)$ respondent to other causes.

\section{Conclusion}

From the findings of this study, it could be clearly noted that the causes of students' learning difficulties in mathematics at senior secondary schools have been greatly influenced by teaching and learning mathematics, because there is scarcity of mathematics teachers at all sampled schools. In each school there are only $4-5$ mathematics teachers.

The outcome of the analyzed data showed that both adequate supply of mathematics teachers and instructional materials greatly can solve the problems of students' learning difficulties in mathematics. The results of this study concurred with the views of some scholars like Walberg (1991), Fafunwa (1979), Fagbamiye (1977), Fayemi (1991), Maronfola (2002), Ngozi (2003) and Jekayinfa (2004).

\section{Recommendations}

Mathematics has always been regarded as a tool for sharpening the intellect. Mathematics therefore, is indispensible to our society. Because of the importance of mathematic to the national development, it is made compulsory to all students of primary and post - primary schools. Base on the findings of this study, the following recommendations were given by the researchers:

1) Government should ensure that qualified mathematics teachers are employed to handle the mathematics lesson in the schools.

2) Government should encourage youths to study mathematics at higher institutions, by giving scholarship and other incentives. This will help to have enough mathematics teachers in the schools.

3) There is need to train and retrain of mathematics teachers, so that they will be up to date with the development of the subject. 
4) The in-service training should be encouraged to enable existing teachers to obtain high qualifications. This will help them to know their subject matter very well.

5) Government should provide adequate instructional materials for teaching mathematics (e.g, math sets, scientific calculator, textbooks, mathematics lab, etc.).

6) Government should provide adequate classrooms to the schools, so that the problems of large class will be solved.

7) There is need for government to organize symposium through state ministry of education, were teachers, parents and students will participate. In this symposium the experts in mathematics education can present a paper about the importance of mathematics and its application to our day-to-day affairs; this will not only help teachers, but it will enable students to have positive attitude towards learning mathematics.

8) There is need for students to be serious on their studies, because the secrete success in mathematics is constant practice.

9) The parents need to encourage their children to study mathematics by providing them facilities like scientific calculator, math sets, textbooks and laptops etc. 


\section{REFERENCES}

Aaron, P.G (1995). Diagnosis of Learning Disabilities School of Psychology Review 24 (3): P. 345 - 360. California U.S.A.

Akintola, B. (2001). "Learning Difficulties in Mathematics at Secondary Schools of Ekiti Central Local Government Area, Ekiti. Journal of Education (EJE) Vol. 5 No.1 P.P. $11-20$.

Azuka, B.F (2000). The Challenges of Mathematics in Nigerian Economic Goals of Vission 2010. A paper presented at the $34^{\text {th }}$ Annual Conference of MAN (Mathematical Association Nigeria) at Federal College of Education Zuba, Abuja. From $1^{\text {st }}-6^{\text {th }}$ September.

Cott, W. (1992). Exceptional Children : Charless Merril Publishing Company, Columbos, U.S.A.

Emerson, J. (2009). "Numbers Sense and its relevance to Dyscalculia." Retrieved from http://www.dsytalk.com on 23/10/2011

Fafunwa, B.A. (1979). “The Purpose of Teacher Education.” In Adaralegbe A. (Ed). A philosophy for Nigerian Education. Ibadan Heineman Educational Books Nigeria Ltd.

Fagbamiye, E.O. (1977). Inequalities in Nigerian Educational Administration. Lagos Education Review. Vol. $1 \quad$ P.P $10-18$.

FGN (Federal Government of Nigeria), (2004). National Policy of Education (Revised Edition), Lagos. Federal Government Press.

Garnett, P.D (1998). Mathematics Learning Difficulties. Journal of Children with learning disabilities. New York, U.S.A.

Jekayinfa, A.A. (2004). The Effect of Instructional materials on the academic performance of students in History. NIJEF vol. 25 No. 1 P.P $1-17$.

Kolawole, E.B \& Oluwatayo, J.A (2006). Societal Mathematics and Information Communication Technology, ABACUS vol. 31 No. 1 P.P $115-121$.

Machiel, R.O. (2008). Factors Affecting Learning Difficulties in Mathematics. A journal of Mathematics Teacher. Vol.18(2), PP. 344 - 351.

Mcloughlin A. (1998). Children and Adolescent with learning disability in Mathematics. Boston, Houghton Mifflin, U.S.A.

National Beraue of Statistic. (NBS), (2016). The 2016 Statistical report of Nigeria.

Obodo G.C. (2001). The problem of teaching and learning Mathematics at secondary school in Nigeria. ABACUS vol. 26 (1). PP. $\quad 60-67$. 
International Journal of Advanced Academic Research | Arts, Humanities and Education | ISSN: 2488-9849 Vol. 5, Issue 9 (September 2019)

Renee, B. \& Louis, C. (2002). Identification of learning disabilities: research to practice. Routedge Publisher. Newyork. U.S.A .

USDE, (2008), United State Department of Education. 